\title{
OS LIVROS DA PRAÇA: DIFERENTES LEITURAS NA ALFÂNDEGA - PORTO ALEGRE / RS
}

\author{
Thais Cunegatto ${ }^{1}$
}

Há tensões complexas no cenário porto-alegrense no que tange às formas de apropriação da zona central, também concebida como "Centro Histórico" da cidade. O intuito deste texto é o de trazer o universo polifônico circunscrito a este espaço urbano, palco de disputas de diferentes atores sociais, com seus estilos de vida diversos e que, por conseguinte, coloca distintos sujeitos em diálogo, sejam eles os habitués locais, os moradores, os transeuntes, os comerciantes, a mídia e o Estado.

Para trazer essa polifonia à tona, o texto em questão analisa um micro-evento no âmbito de um evento maior, cujo cenário é a Praça da Alfândega.

A Praça da Alfândega está situada no centro de Porto Alegre, mais especificamente na Rua da Praia. A praça constituiu-se ao longo do tempo um território de enraizamento e de trocas sociais pautadas na heterogeneidade social e cultural dos indivíduos e/ou grupos que por ela são atraídos. Sendo assim, trata-se de um espaço singular da cidade, marcado por intensas trocas sociais acumuladas ao longo da passagem do tempo. Embora toda Rua da Praia esteja implicada em conflitos, é no território da praça - uma espécie de coração do centro - que se evidenciam os conflitos e dinâmicas que analisarei.

Trago as tensões urbanas que emergem das interações entre personagens urbanos entre si e destes em relação a cidade, esta última sujeita às ações do Estado. Portanto, estão envolvidas questões entre "a casa, a rua e outro lugar", conforme aponta Roberto Da Matta (1985), para tentar elucidar a forma como os atores sociais distintos, com estilos de vida e ethos diferenciados, disputam e vivenciam o mesmo espaço urbano, no caso, a Praça da Alfândega, um dos "subespaços"” (DA MATTA, 1985, p. 48) da Rua da Praia.

Essas tensões e conflitos se dão em múltiplas formas e situações. Trago o relato de uma experiência que dimensiona um evento, em sua densidade: o episódio do roubo do livro da estátua de Carlos Drummond de Andrade e seus desdobramentos narrativos e discursivos, ocorridos na Feira do Livro em 2007.

\section{"O livro roubado"}

Nos bancos da Praça da Alfândega, sentam-se senhoras e senhores de idade avançada, donas de casa, vendedores de cafezinho, prostitutas, jogadores de dama, engraxates e é também onde se localiza a estátua de Mário Quintana: que é retratado sentado em um desses bancos, olhando para a estátua do amigo e poeta Carlos Drummond de Andrade enquanto esse lê em pé um livro embaixo das frondosas árvores da praça. Ambas as estátuas foram feitas em 2001, pelos artistas Francisco Stockinger e Eloisa Treguajo.

Em meados do mês de outubro de 2007, véspera da $53^{\text {a }}$ Feira do Feira do Livro, todos preparativos estão em andamento: ergue-se a lona, as barracas começam a ser montadas, os

\footnotetext{
${ }^{1}$ Antropóloga pela Universidade Federal do Rio Grande do Sul, Doutoranda em Antropologia pela Université Laval - Québec (Canadá). E-mail: tcunegatto@gmail.com.

${ }^{2}$ A casa e a rua, de acordo com Roberto Da Matta, estão em uma relação complementar de oposição, pois “a rua tem seus espaços de moradia e /ou de ocupação, e a casa também tem seus espaços arruados" (1985:48). É, assim, neste interstício que se encontra o espaço das praças públicas que ao abrigarem características tanto da "casa" como da "rua" tornam-se "subespaços" com temporalidades distintas.
} 
livros encaixados, a praça de alimentação começa a ser montada. A Praça da Alfândega é preparada para sediar o grande evento cultural da cidade de Porto Alegre. Seus espaços serão repletos de pessoas por todos os lados: adultos, crianças, idosos, adolescentes. A classe média prepara-se para visitar o centro da cidade. Eis que um problema de "segurança pública" surge no espaço em que tal evento acontecerá: o livro de bronze é roubado das mãos da estátua que homenageia o poeta Carlos Drummond de Andrade.

Zero Hora, dia 18 de outubro de 2007

Opinião ZH

E agora José (Fogaça ou Franscisco Mallmann?) O livro sumiu/das mãos do poeta/no meio da praça/saiu no jornal/o povo notou,/a polícia nem viu/nem a guarda municipal./E agora, José/ Você diz o quê?/que é apenas um empréstimo/ e vão devolver?/ Não dá pra crer. / E agora, José?/ Você que faz versos/que canta a cidade/de um jeito legal/ etecétera e tal,/você acha normal, /ou acha demais?/ E agora, José?/Você que comanda/ a força legal /que manda prender /não deixa beber/ e crê na oração, /vai achar o ladrão?/ E agora Drummond? E agora Quintana?/Vocês que estão longe,/que viraram bronze,/ por que não gritaram?/ Se vocês gritassem/ se vocês gemessem, / se vocês tocassem, / a valsa vienense,/ talvez evitassem/ o furto e a vergonha/ do povo riograndense.

\section{Coluna Paulo Santana}

Agora roubaram o livro das mãos do Drummond. Qualquer dia vão roubar o corpo inteiro do Drummond, depois a estátua inteira do Quintana. Vão roubar tudo. Eu não posso entender como gente minimamente inteligente não percebe que os parques e praças abertos à noite significam destruição.

É a mais esférica imbecilidade investir diariamente nos parques e nas praças e ver tudo que é investido é dilapidado diariamente.

Não fechar os parques e praças à noite é, portanto, uma rotunda imbecilidade.

Saída a campo dia 25 de outubro de 2007

Eu: Frida, você sabe do roubo do livro? Deu até no jornal.

Frida: Tiraram o livro, tem o Mario Quintana e aquele outro lá o Andrade, só não levaram eles porque é muito pesado e é grudado no asfalto. O povo já disse daqui a pouco vão levar estes homens daqui, ainda não levaram porque é pesado, levaram só o livrinho.

Eu - Tinha gente até falando em cercar a Praça no jornal...

Enquanto ri um sorriso amarelo, Frida responde: "Daí fica ruim, porque vão tirar nós daqui”".

É na Praça da Alfândega que encontro Cândido, um habitué do local que descreve seus diversos grupos:

Aqui tem de tudo: têm os caras ali que jogam dama, fazem até campeonato, estão sempre aqui; têm os aposentados que ficam perto dos engraxates; têm as prostitutas; têm os feirantes da feirinha ali atrás; e têm nós. Aqui todo mundo se conhece e sabe da vida de todo mundo, se tu continuar vindo aqui, vai saber também, dá até pra escrever um livro!

O "nós" a quem Cândido se refere é o grupo com o qual me relacionei entre junho de 2007 e abril de 2008. Entrei nessa rede por intermédio de Frida, que me apresentou a Vera, a Alemoa, e o 
Cândido, conhecido como professor. Todos eles se encontram sempre na Praça da Alfândega para "jogar conversa fora", comer, chorar, sorrir, ou simplesmente o que tiver que ser.

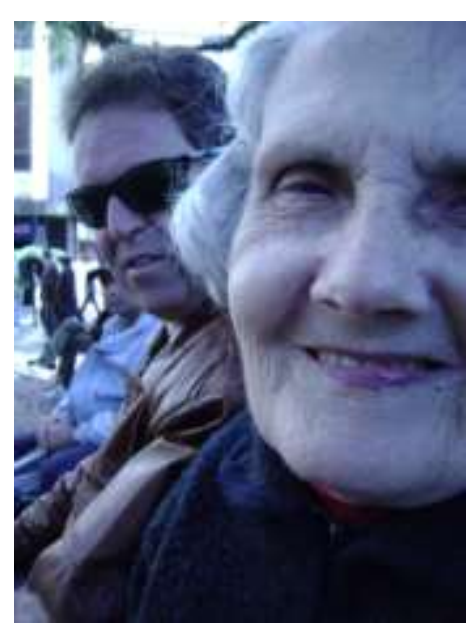

Frida é uma senhora de 82 anos, nascida em Dois Irmãos, cidade onde trabalhou na lavoura até a morte de seu marido, quando migrou para Porto Alegre com seu filho. Aqui trabalhou como empregada doméstica até se aposentar. Pergunto a Frida qual a importância da Praça da Alfândega para a sua vida, se as suas idas cotidianas ao espaço da praça deviam-se aos amigos que ela encontra no lugar. A sua resposta mistura lembranças familiares com o seu cotidiano atual.

Não, amigos eu tenho sim, venho aqui há 30 anos, fiz vários amigos, uns já morreram, outros se mudaram. Tenho umas amigas aqui, mas venho aqui e me sento todos os dias na frente deste prédio para me lembrar de meu filho, que trabalhava ali, ó, naquele andar. Venho matar a saudade, parece que a qualquer momento ele vai sair dali.

Obviamente Frida não fica apenas sentada em um banco da praça relembrando nostalgicamente o passado. Suas idas diárias à Praça da Alfândega também são o resultado de uma rede de reciprocidade a qual pertence e que, embora alguns personagens mudem acaba se mantendo ao longo do tempo.

Frida mora em um quarto de hotel na Avenida Farrapos, zona marcada pela existência de prostíbulos. Com aposentadoria de um salário mínimo somado à ajuda de seus amigos da Praça, ela se sustenta. Seu filho mora em Dois Irmãos e, segundo ela, por causa da nora, que "não gosta de velhos", pouco o vê. Sobre este assunto, Cândido segreda que a maioria dos velhos que ali estão, na realidade, são solitários e carentes, permanecendo na praça para o tempo passar e ter com quem conversar, porque "estão abandonados e não têm ninguém". Ele relata outros três casos de senhores que sempre estavam ali e que se encontravam na mesma situação de Frida, um deles já havia morrido. Este senhor que não conheci se chamava Jarbas; sobre ele, Frida contou: "Ele teve uma morte feliz, morreu aqui no banco da Praça."

Eis aqui um caso típico que Michel Maffesoli (1994, p. 64) apontaria como um "espaço de celebração", onde o denominador comum é o lugar da sociabilidade que acolhe o sentimento de pertença. São as celebrações do corpo, da imagem, da amizade, da comédia, do esporte, quaisquer que sejam os motivos em celebração, são ali desenrolados, pois o próprio lugar é "laço" que une seus habitués. Lugares como a Praça da Alfândega tem a pontecialidade de tornar até mesmo a forma da perda (do amigo) um acontecimento afortunado, porque ela acontecera no "espaço de celebração" de onde a felicidade emana. 
Jornal Já, 02 de novembro de 2007

A entrevista coletiva para apresentar as novidades da $53^{\text {a }}$ Feira do Livro de Porto Alegre, na manhã da quinta-feira, 18 de outubro, transformou-se em um ato de protesto. Motivados pelo roubo do livro que a estátua de Carlos Drummond de Andrade segurava - o monumento de Xico Stockinger, localizado na Praça da Alfândega, homenageia também o poeta Mario Quintana - o patrono do evento, Antonio Hohlfeldt, e o presidente da Câmara Riograndense do Livro, Waldir da Silveira, condenaram o ato e garantiram que "o vandalismo não vai interferir na Feira".

Silveira tranqüilizou os freqüentadores quanto à segurança na Praça. $\mathrm{O}$ presidente da CRL acredita que o problema não vai se repetir. "Temos um esquema garantido pela Brigada Militar que é excelente", observa Silveira. O livro roubado será devolvido às mãos de Drummond em uma cerimônia, ainda sem data prevista, que vai marcar a instituição do Dia Contra o Vandalismo na capital do Estado.

Além da condenação pública do ato, a "arma" na qual a organização aposta suas fichas para combater o vandalismo é a ação social. "Esse não é um evento só de literatura, mas também de cidadania", salientou Hohlfeldt. (...). Naira Hofmeister

Com a eminência da Feira do Livro, evento anual que marca há 54 anos a cidade de Porto Alegre, algumas vozes emergiram acerca da segurança pública da Praça da Alfândega, espaço de sociabilidade no qual o evento ocorre. O roubo do livro desencadeou um processo já antes existente, por sinal, latente. Porém, desta vez "publicizado": "O que fazer para manter a segurança na praça durante a Feira do livro?" Esta é a pergunta de jornalistas e da guarda municipal. Outra pergunta que emerge de outros personagens é: "O que farão conosco, que sempre estamos aqui na Praça, durante a Feira do livro?", indagavam os atuais habitués do espaço.

A Feira do Livro é um evento que evidencia, portanto, uma tensão pré-existente e levanta perguntas, como: a quem "pertence" a Praça? De quem e para quem é a Feira do Livro? Uma resposta simples, apontaria o fato de que tanto a Praça da Alfândega quanto a Feira do Livro são espaços destinado aos cidadãos porto-alegrenses. Pois bem, que cidadãos são estes? O que significa ser cidadão neste contexto urbano?

A antropóloga Cláudia Fonseca (1994), em seu texto “Antropologia, Educação e Cidadania"3 coloca-nos frente a algumas respostas possíveis para tais perguntas, no que se refere, especialmente à questão da cidadania em um país como o Brasil, cujas desigualdades sociais, econômicas e políticas são alarmantes e "ultrapassam o limite da imaginação", como esclarece a autora.

Essas desigualdades são responsáveis pela situação de "apartação" reinante, na qual, muitas vezes, "rico" e "pobre" só se encontram em situações de faxina ou assalto. Por um lado condomínios de luxo, rodeados de grades de ferro, por outro, favelas que se estendem até os quatro horizontes, levando a justaposição na mesma sociedade, de modos de vida radicalmente diferentes um do outro. (FONSECA, 1994).

Essa estrondosa desigualdade social acaba por refletir nos domínios do espaço público. O antropólogo Roberto Kant de Lima (2001) mostra como as concepções de espaço público são crucias para a compreensão do regimento deste. Trazendo diferenças entre as concepções geridas na França, nos Estados Unidos e no Brasil, o autor demonstra que a própria concepção

3 Texto retirado do site <http://www.smec.salvador.ba.gov.br/site/documentos/espaco-virtual/espacoescola/professor/artigos/antropologia....pdf $>$. 
brasileira de "espaço público" está baseada em uma pré-noção de que o público é "apropriado particularizadamente, seja pelo Estado, seja por membros da sociedade autorizados ou não por ele" (KANT DE LIMA, 2001, p. 04).

Portanto, trata-se de um espaço aparentemente caótico para quem não compartilha os seus códigos de apropriação. Sendo assim, a construção da ideia de "igualdade" pauta a "semelhança" (apenas para quem pertence ao mesmo universo de sentido) e não a "diferença" entre as pessoas.

Assim, o Estado cumpre um papel totalitário regulamentando quem são os "cidadãos" que podem ou não usufruir de tal espaço público. Tal dilema gera, assim, "negociações (do espaço público) que se tornam deslocamentos estruturais, que afetam posições desiguais em uma hierarquia excludente" (KANT DE LIMA, 2001, p. 05).

Neste contexto devemos repensar o que significa ser "cidadão", quando, a princípio, todos seriam providos dos mesmos direitos de uso do espaço público, mas que, na prática, "uns são mais cidadão que outros", podendo restringir, mesmo que por ação do Estado, o acesso de determinados cidadãos a determinados espaços e momentos específicos, como foi o caso das prostitutas, dos feirantes e dos vendedores de comida na Praça da Alfândega no evento Feira do Livro.

A Praça da Alfândega é um espaço público, uma res publica, na qual atualmente as pessoas oriundas das camadas populares sociabilizam diariamente e constroem suas identidades, afirmando-se como pertencentes àquele espaço: "Sou da Praça", diz um engraxate. Dessa forma, tendem a se apropriar do espaço, particularizando-o como o seu lugar, de acordo com seus códigos de postura e de sociabilidade.

Este discurso pode ser ouvido nas vozes trazidas por Heloísa Corrêa Gravina (2006), que, ao relatar seu estudo sobre a Praça da Alfândega, também traz a seguinte pergunta: "De quem é a Praça?" A autora vê nas prostitutas que configuram este espaço um processo de construção identitário vinculado à Praça da Alfândega: "Sou prostituta da Praça da Alfândega". E, assim, percebe-se que grupos distintos afirmam sua identidade por meio de um espaço da cidade, como é o caso da Praça da Alfândega.

Obviamente isso não significa dizer que a Praça da Alfândega é de fato destes habitués, mas, com certeza, são estes personagens que a compõem e a conformam, dinamizando parte do seu cotidiano.

Outra pergunta que fica: "Para quem é a Feira do Livro?". A Feira é um evento anual que busca promover a cultura escrita, a adoração ao universo livresco. Com apoio fiscal, os livros durante este evento têm seus preços reduzidos em cerca de $20 \%$. A Feira do Livro, no entanto, como já colocou Heloísa Gravina ao relatar suas impressões do que seria o evento para nós, membros da "classe média intelectualizada", é um "evento mágico", que permite que vejamos o centro de Porto alegre com outros olhos, levando-nos, assim, até ele; é um evento "popular" de consagração ao livro.

Frida ao relatar as impressões de seus amigos sobre a Feira do livro desabafa, afirmando que um deles se recusa a passar pela Alfândega durante a Feira, pois "roubaram a nossa Praça".

Nesse sentido, pode-se perceber que durante a "Feira do Livro" a lógica de apropriação da Praça da Alfândega é alterada mediante as ações do Estado, que buscam moldar o espaço de acordo com a lógica dos "estratos médios", a fim de que estes possam deambular sem constrangimentos morais naquele que é um espaço público (proibindo a circulação das prostitutas, dos vendedores de cafezinho e de qualquer "elemento" inoportuno). 


\section{O livro de Drummond}

Dia 25 de outubro de 2007

Excerto de diário de campo,

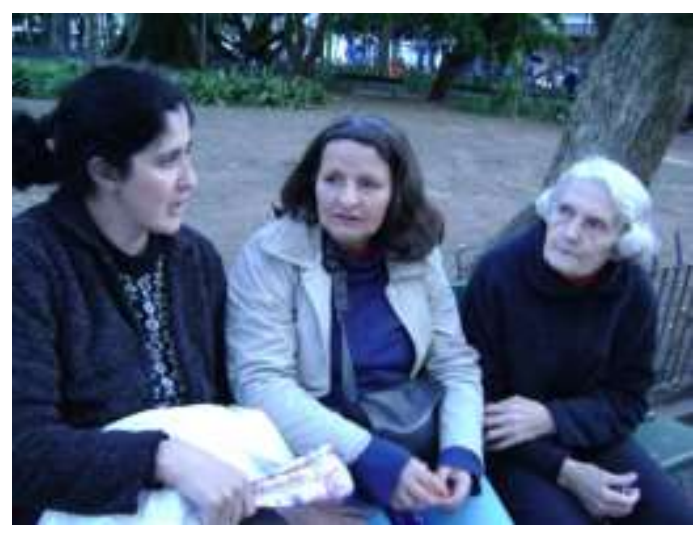

Estávamos sentados em um banco, em frente a uma banca de livros que começava a ser montada. Arrumavam os livros, separavam os saldos "a cinco reais". Cândido, Frida, Seu Adão e eu observávamos. Cândido e Seu Adão confessaram que não suportavam a feira, pois ela mudava tudo e, além de tudo, segundo Adão, a própria feira havia mudado, pois antes os governantes pelo menos enfeitavam a praça com flores, hoje nem isso. A feira apenas "enfeia a praça". Cândido complementa que a praça é pequena demais para abrigar tamanho evento; a Feira do Livro deveria se mudar para o Cais do Porto, que, segundo ele, é bem mais espaçoso, mas Adão corrige "é uma questão de tradição" que a Feira se mantém ali, e, por isso, ela não se muda, todos é que mudam por causa da feira.

Perguntei se eles continuavam frequentando a Praça nos dia de Feira, se conseguiam se encontrar, como de costume. Eles afirmaram que embora não gostem do evento, continuam indo ali. Frida confessa que já gostara da Feira, mas agora é muita gente, não dá para ver as pessoas circularem e, além de tudo, tem que chegar muito mais cedo para conseguir um banco livre durante a Feira.

Seu Adão é um senhor negro, por volta dos 70 anos. Todas as vezes que eu o vi na praça, ele estava bem alinhado, de terno, gravata, sapatos bem engraxados. Seu Adão e Cândido saem. Adão vai até a Igreja, pergunto a qual, e ele diz que é a Universal, igreja que o "salvou, pois agora ele não bebe e não fuma", por isso é muito devoto. Vai à Igreja todos os dias.

Permanecemos Frida e eu, tento saber um pouco mais sobre o que ela pensa da Feira do Livro, pois enquanto os homens estão próximos, ela pouco fala, a fala fica destinada ao masculino, por mais que eu tente dar voz a ela. Frida enfatiza que quando não tinha amigos gostava da feira, pois se distraía, mas agora, é um problema, pois muitos deles se recusam a estar lá durante o evento. Além disso, um grande problema é que os vendedores de cafezinho não podem circular na Praça durante a feira, pois a SMIC proibiu o comércio. Pergunto por quê? Frida garante que é só para ganhar dinheiro e tirar o trabalho de seus amigos. Ela compara o trabalho dos vendedores de café, com o dos camelôs que volta e meia fazem manifestações ali por causa da apreensão das mercadorias por parte da SMIC. Eu permaneci com o gravador ligado durante a conversa com Frida e, agora, tentando reescutar a fita, retiro algumas frases ditas por ela que narram o evento dos camelôs: 
"Camelô veio vindo", "Polícia é ladrão", "não deixa nós trabalhar", "polícia é ladrão", e diziam que ia "quebrar tudo", eles vieram aqui três vezes, eles querem quebrar tudo. Frida fala que apesar de ter pouco estudo ela acha que não são os fiscais da SMIC os responsáveis "porque eles só obedecem regras de quem manda de verdade e que a revolta dos camelôs não está certa, porque eles ameaçaram quebrar as lojas que ficam ali na Rua da Praia e isso é injusto porque os lojistas não têm culpa também".

Mas, segundo ela, a proibição da venda do cafezinho também é injusta, pois "a pessoa tem que comer, tomar suco e café, mas a SMIC briga com os camelô e não deixa, não deixa vender cafezinho". Ela conta sobre duas vendedoras de comidas e bebidas que possuem família para sustentar - tem a mãe e os filhos - e estão impedidas de trabalhar: "elas vendem bem aqui e agora não podem trabalhar, eles não querem que venham aqui". Conta que os vendedores de comida e bebida que antes circulavam pela Praça agora ficam ao seu redor, tentando vender para os clientes fiéis que vão até onde estão, para comprar seus produtos.

Danilo, que também é vendedor de cafezinho não estava ali e "apesar do café dele ser ruim, ele tem que ganhar dinheiro". Frida conta que compra "das guria", na verdade ela corrige, que não é ela quem compra e sim suas amigas porque "eu não tenho dinheiro, mas compram pra mim!"

Estávamos embaixo da marquise, em uma espécie de teto que cobre a feira e deixa o espaço bem abafado, sentadas num banco onde o sol queimava em nossas costas, "mas era o lugar que tinha", desabafa Frida. O calor é insuportável e eu mesma começo a ficar com raiva da SMIC, pois tudo o que queria era alguém que passasse por ali e me vendesse uma água.

Ainda sobre a feira, Frida revela que no ano passado ela fez amizade com o pessoal de uma banca de livros que ficava exatamente na frente de onde estávamos. Pergunto se é a mesma banca, mas ela disse que não sabe se é a mesma banca, pois as pessoas não são as mesmas.

A Feira do Livro embora altere totalmente a lógica dos habitués da Praça da Alfândega encontra-se em um misto de adesão e repulsa por parte deles.

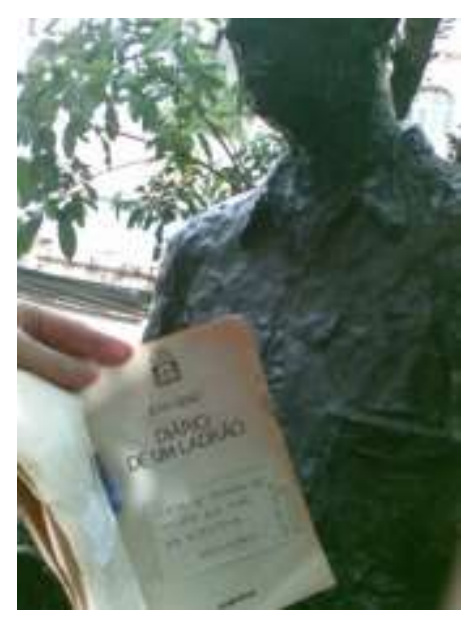

No domingo, dia 04 de novembro de 2007, estive na Feira do Livro e encontrei tanto Frida quanto Seu Adão; ambos estavam "escondidos", tapados por uma banca, mas lá estavam. Resistência, adesão ou apenas uma prática cotidiana?

O roubo do livro serve aqui como metáfora dessa tensão que pré-existe. Mas a cena que descreverei aqui também serve como metáfora das estratégias de permanência que estes habitués praticam em sua estada durante o evento. 
O livro roubado causou alvoroço, notas em jornais e discussões públicas, ou seja, uma série de discursos emergiu a partir desse incidente. No domingo em que estive na praça, tanto Frida quanto Seu Adão e as estátuas de Quintana e Drumonnd também lá estavam... Mas havia algo diferente: o que tinha nas mãos de Drummond? Vejam só...um livro.

Havia tumulto perto das estátuas, todos paravam para ver o que estava acontecendo. Será que queriam ver a falta do livro? Ao me aproximar, percebo um cenário montado: duas mulheres sentadas no banco à frente das tão famosas estátuas, enquanto um lambe-lambe tira uma foto de ambas. Nas mãos de Drummond, um livro, não o bronze, aquele roubado, mas um livro já amarelado, no qual o vento revolta as folhas que esvoaçam está sobre as mãos da estátua. Pessoas param para olhar, também vou até a estátua de "Drummond" e lá está um livro, cujo título inusitado para a situação é "Diário de um ladrão". Dentro do livro há um bilhete "Leia, e ponha de volta na mão da estátua. Obrigado. 27-10-2007”. Pergunto ao lambe-lambe se tinha sido ele quem tinha colocado o livro ali, o homem afirma que sim, mas que teria que restaurálo, pois todos ali paravam para ver a façanha do novo livro.

O espaço das estátuas tem sido um ponto de atração desde a sua inauguração em 2001. Frida afirma que as pessoas vão sempre ali para tirar fotos. Sendo o ofício de lambe-lambe tirar fotos, o que faria ele senão aproveitar o incidente das estátuas como estratégia de venda, e, assim o fez. Filas e filas lá estavam para tirar fotos com o "novo" livro que Drummond oferecia a Mário Quintana.

A história que acabara de vivenciar me deixou intrigada. Volto para casa e navego na Internet em busca de informações: a busca é feita pelas palavras "roubo do livro". Diversas matérias em jornais virtuais e blogs esboçam distintas opiniões e dentre elas, aparece uma matéria intitulada "tinha um livro no meio do caminho", depois desta, várias outras me revelam a outra face da mesma história proferida pelo lambe-lambe.

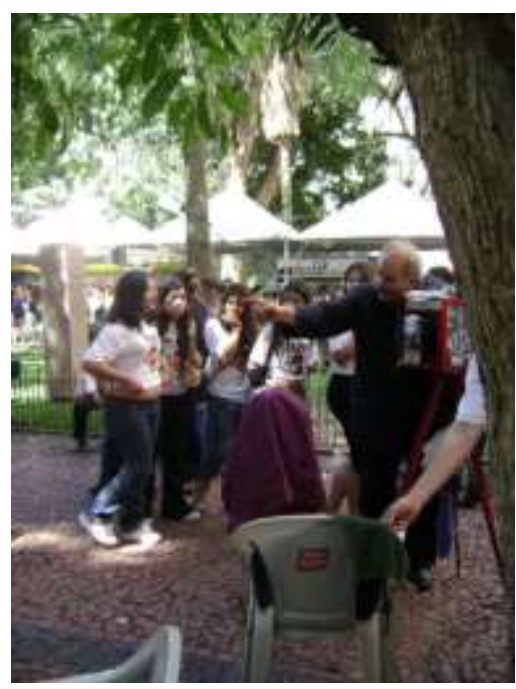

Descubro que o lambe-lambe chama-se Varceli Freitas e que, na verdade, ele não foi o autor da ideia de colocar nas mãos de Drummond o livro "Diário de um ladrão", como supunha a partir de nossa conversa, mas sim, seu guardião. O livro "Diário de um ladrão", título do francês Jean Genet, surgiu da biblioteca do jornalista e chargista gaúcho Augusto Bier que, em uma atitude de protesto, o colocou sobre as mãos da estátua. "Tive a ideia de colocar o livro na estátua para chamar a atenção para o desamparo da estátua sem o livro, um desamparo que é também nosso" - comenta Bier, 48 anos, natural de Santo Ângelo, para o jornal Zero Hora.

Varceli Freitas zelava pelo livro, recolhia-o todos os fins de tarde, levando-o para sua casa, para que não tivesse o mesmo destino do livro de bronze de Drummond. Lendo a reportagem da 
Zero Hora pude compreender a sua conversa comigo, pois o lambe-lambe desabafa ao repórter: "Já teve quem quis passar a mão, quem quis comprar. Estou dizendo que o livro é meu porque, se não for assim, o pessoal não respeita e leva. Levo e trago todos os dias, se preciso."

E assim o fez. Levou e trouxe todos os dias em que ocorreu a feira. O livro era o espetáculo da Praça da Alfândega e, por conseguinte, da Feira do Livro. A reposição do livro não era apenas uma brincadeira, era um protesto que impunha mistério e fascinação aos visitantes. As pessoas ali paravam e fotografavam - inclusive, tirando fotografias suas junto à estátua - fosse com Varceli, com suas máquinas digitais, ou mesmo, com o celular.

Ao saber de toda a repercussão de seu protesto Augusto Bier exclamou: "Que ótima notícia. Esse livro não é meu mais. É do Drummond. E é nosso!"”.

O livro permaneceu até o dia 06 de novembro, quando também foi tirado das mãos de Drummond sem Varceli perceber. O lambe-lambe, em uma reportagem para Zero Hora, explicou: "Tinha uma gurizada cercando a estátua, e eu estava aqui cheio de trabalho e me distraí. Quando olhei de novo, já não estava mais".

Mais rápido do que o esperado, o livro de bronze foi reposto, devolvido às mãos de Drummond, no dia 7 de novembro. No entanto, seu livro ficou coberto por um tapume até o dia 9 de novembro. Houve uma cerimônia solene para reposição, com a presença dos escultores da peça Xico Stockinger e Eloísa Tregnago, bem como a do prefeito da cidade, José Fogaça.

\section{A volta à rotina}

Em busca das narrativas emergentes nesse cenário urbano e, para elucidar as diversas questões oriundas da leitura das notícias, vou a campo no domingo seguinte, dia 11 de novembro de 2007. Puxo conversa com uma senhora. "Ah o livro da estátua está ali de novo?" Ela afirma que sim e já começa a falar do absurdo do vandalismo, mas que isso não era privilégio nosso, pois em Copacabana tinha acontecido o mesmo! Esboço surpresa, ela diz que sim, que roubaram uma estátua em Copacabana.

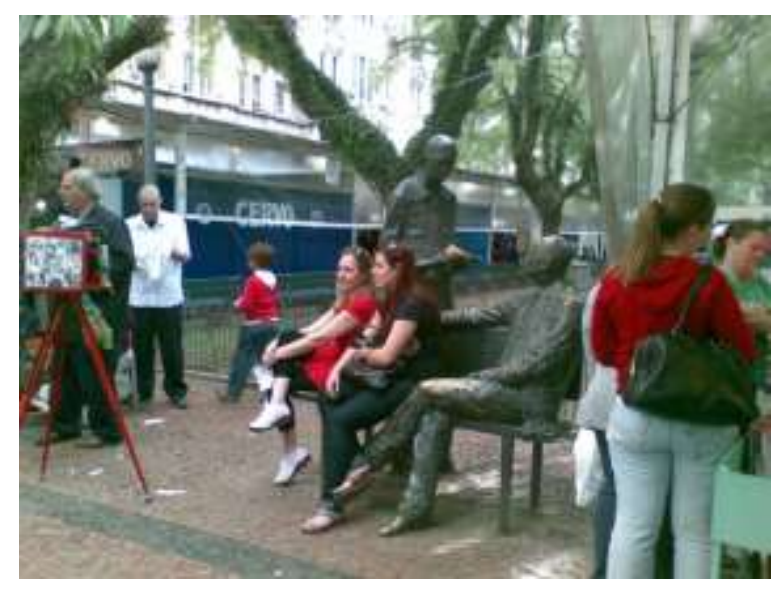

Enquanto isso, várias pessoas param perto do banco da praça para tirar fotos junto às estátuas de Drummond e de Quintana, algumas com seus celulares, outras com a câmera digital. Uma pessoa tira foto da outra, um revezamento de amigos que passam a alternar o papel de fotógrafo. O lambe-lambe aproveita e diz para um casal que espera na fila: “Ó, aproveitem que agora o banco está vazio, não tem ninguém tirando fotos".

Os bancos costumam ser disputadíssimos, como explicou Frida em outro momento; são tidos como um espaço de descanso. "Há que chegar antes para ter um lugar bom para sentar", mas este banco, embora seja disputadíssimo, não tem apenas a função de assento, pelo menos 
no evento Feira do Livro. Ele serve para tirar fotos, como um ponto de amarração da memória do lugar; mais ainda, estas fotos servem para testemunhar, ou o roubo do livro de bronze (há três semanas), ou o livro recolocado temporariamente pelo lambe-lambe (há uma semana), ou mesmo, o livro de bronze recolocado (nesta semana). As fotos tiradas tanto com celulares, máquinas digitais como pelo lambe-lambe, narram o episódio do roubo do livro e seus desdobramentos. Não quero dizer com isso que antes as fotos não fossem tiradas, obviamente já fotografavam as estátuas. Até onde sei sempre se tirou fotos, mas desta vez foi um acontecimento. Todos paravam para ver a estátua, comentavam, apontavam, tocavam e, por último, imortalizavam o momento pelo clique fotográfico.

Esta é a estátua do roubo! Até onde vai o vandalismo! Olha ali, o livro tá de novo, no início da Feira não tava! Olha o livro que tá ali, quem era que botou? Tem que prender o vagabundo que faz isso, onde já se viu!

Primeiro, as frases rápidas e algumas brincadeiras, depois, um clique fotográfico. Mudam as pessoas que opinam e relembram o roubo do livro, mas a função permanece. Mais uma senhora passa e comenta com o marido: "Ah tu viste que roubaram os óculos da estátua no Rio de Janeiro", daí já eram duas pessoas, e uma informação a mais: foram os óculos que roubaram, mas de qual estátua do Rio de Janeiro?

Pergunto ao ajudante do lambe-lambe quando recolocaram o livro de bronze. Ele afirma não saber, mas que devia ter sido na sexta-feira. Comento com ele sobre o livro que estava ali na semana passada, e ele retruca "que livro? "Ah sim, o "Diário de um ladrão". Mas não dá muita conversa, penso estar importunando, pois trabalho é o que não falta para ele.

Permaneço parada mais um pouco, pensando sobre a diferença dos tempos fotográficos. Um casal senta no banco da estátua para tirar fotos com o lambe-lambe. Ajeitam-se, fazem poses, beijam-se, abraçam-se, sempre voltados para a câmera, quando de repente Varceli sai debaixo do tapume preto da câmera escura e diz que irá começar a fotografar. O casal não entende muito bem, afinal de contas já não estavam sendo fotografados? Estavam posando para a fotografia todo aquele tempo e só agora começaria a sessão fotográfica? Varceli explica que ele estava coberto pelo tapume porque estava finalizando uma outra fotografia retirada anteriormente. Sendo assim, o casal retorna a fazer poses. Enquanto isso, a senhora com quem converso, a dona das fotografias que estavam sendo finalizadas, já está esperando há 10 minutos pela sua foto. Naquele meio tempo, entre a fotografia a ser finalizada e outra a ser retirada, no mínimo 10 pessoas foram até o local e tiraram inúmeras fotografias com suas câmeras digitais e logo foram embora.

\section{A Feira do Livro como um evento performático}

A intenção de analisar a Feira do Livro como um evento performático, ou ainda, na concepção de Victor Turner (1974), como "um drama social" pareceu-me adequada a partir dos estudos na disciplina desenvolvida pela professora Maria Elisabeth Lucas (PPGAS, UFRGS), bem como a possibilidade de analisar, mediante tal noção, as experiências que registrava durante as saídas a campo. As conversas com os habitues da Praça, que previam o "inferno" que seria a Feira do Livro, que começaria dali há uma semana, também me ajudaram a optar por aquele caminho. A minha primeira reação foi de espanto, pois pelo que soubesse a Feira começaria em por volta de umas três semanas. A partir da pergunta "mas não é daqui a um mês?", obtive a resposta "sim, mas os preparativos começam duas semanas antes; a feira para nós dura mais de um mês, porque tem o antes, o durante e o depois. É um inferno!", afirmou Cândido. Empolguei-me. Pensei é isso! A Feira do Livro como um evento performático. 
Obviamente, esta não foi uma análise inédita. Como Gravina apontou, "analisar a Feira enquanto um ritual é relativamente simples: um acontecimento extraordinário, que interrompe o fluxo cotidiano e instaura uma nova ordem, temporariamente, num espaço determinado" (GRAVINA, 2006, p. 107) Mas, como a autora também o fez, gostaria de ver este evento a partir de uma perspectiva êmica, ou como ela coloca, pelas "margens", à luz da teoria do "processo ritual" de Victor Turner (1974).

O que ressalto aqui é o que Tambiah (1984) já apontava, ou seja, a emergência desse ritual; as pequenas transformações no cotidiano; os discursos que vêm à tona e saltam aos olhos; a tensão que cria entre os diversos agentes sociais e, mesmo, a união instaurada entre os grupos que a frequentam, pois personagens que antes buscavam se distinguir, como as prostitutas e as velhinhas aposentadas, unem-se como uma espécie de "communitas" "identitária "Somos da Praça". Por mais que Frida ressalte que "cada um tem o seu lugar", é exatamente o não respeito ao "lugar deles" que gera durante esse evento performático a existência desta communitas.

Segundo Stanley Tambiah (2003, p. 11), numa Tradução feita por Marisa Peirano:

O ritual é um sistema cultural de comunicação simbólica. Ele é constituído de sequiências ordenadas e padronizadas de palavras e atos, em geral expressos por múltiplos meios. Estas sequiências têm conteúdo e arranjo caracterizados por graus variados de formalidade (convencionalidade), estereotipia (rigidez), condensação (fusão) e redundância (repetição). A ação ritual nos seus traços constitutivos pode ser vista como "performativa" em três sentidos: 1) no sentido pelo qual dizer é também fazer alguma coisa como um ato convencional (como quando se diz 'sim' à pergunta do padre em um casamento); 2) no sentido pelo qual os participantes experimentam intensamente uma performance que utiliza vários meios de comunicação (um exemplo seria o nosso carnaval) e 3), finalmente, no sentido de valores sendo inferidos e criados pelos atores durante a performance (por exemplo, quando identificamos como 'Brasil' o time de futebol campeão do mundo).

Assim, esse sistema cultural de comunicação simbólica informa como o livro de bronze, ou mesmo o "Diário de um ladrão", indicam tensões que pré-existem; revela um espaço social, o da Praça da Alfândega, que, devido à sua beleza e ao seu valor monumental, deve ser "higienizado", segundo a visão das camadas médias e a manifestação governamental, como prevê o Projeto Monumenta. Portanto, este deve ser um espaço "cercado", cuja presença dos "vândalos" e dos "marginais" que o frequentam e que, por ventura, roubam os seus símbolos sagrados precisa obrigatoriamente ser barrada. Mas, ao mesmo tempo, mediante estudo etnográfico é possível revelar que a praça é um espaço de intensa sociabilidade marcada por trocas sociais e de reciprocidade entre pessoas que buscam o direito de "estar lá". A Praça da Alfândega constitui-se, portanto, um cenário, ou ainda, um palco para esses conflitos, que são comunicados por meio de um evento performático: a Feira do Livro.

A relação de trocas sociais vivenciadas no seio de uma metrópole, através da lógica da moeda, aponta para o processo de globalização, cuja faceta capitalista possui força exacerbada. Nestas linhas, busco dialogar com Jill Lane (2002), que ao analisar as performances de Bill Talen, como Reverendo Billy, nas pregações da Church of Stop Shopping, demonstra que a criação dessa performance é uma reação política ao processo violento de mercantilização que transforma cidadesmetrópoles, tais como Nova York ou, mesmo, Porto Alegre. Podemos, assim, compreender tanto o roubo do livro de bronze em meio à inauguração de um evento extraordinário como a Feira do Livro

\footnotetext{
${ }^{4}$ Ver a obra de Victor Turner “O processo ritual: estrutura e antiestrutura”. Petrópolis: Vozes, 1974.
} 
como a recolocação de outro livro intitulado "Diário de um Ladrão", como formas de protesto político que questionam a ação do Estado frente ao bem público, ao mesmo tempo em que interrogam acerca das atitudes dos cidadãos que interagem e sociabilizam neste espaço.

Conforme coloca Jill Lane (2002), tais protestos políticos, como a performance do reverendo Billy e, no caso que nos interessa, a performance do lambe-lambe, quando se mantinha como autor da ideia da recolocação do livro "Diário de um Ladrão", com a investidura do cargo de guardião, provocam públicos desprevenidos que participam de uma cena reveladora como atores desta. Para a Praça da Alfândega, as discussões trazidas levantavam os temas do vandalismo, da violência urbana e do descaso público, questões latentes que foram provocadas e emergiram neste protesto, concebido como uma resposta irônica às ações políticogovernamentais, seguindo também a lógica de atuação proposta por Bill Talen.

Jill Lane aponta que ao narrar as histórias do processo de criação dos produtos que são, na verdade, processos de exploração e mais valia, depositados nos bens de consumo, Bill Talen busca renarrar e ressignificar momentaneamente os cenários de sua performance (Disney, Mcdonalds). O performer traz à tona uma história de exploração, camuflada na fabricação do "lugar dos sonhos", afim de ressignificar este espaço e fazer dele momentaneamente um lugar reflexivo, esclarecendo para a platéia, como estes espaços são fruto de um processo de desigualdade e escravização do outro.

Dessa forma, Augusto Bier provocou, em seu protesto, a ressemantização do espaço, que passou a ser um locus de atração e, ao mesmo tempo, de reflexão sobre o descaso do Estado com a violência urbana. A ação do chargista foi provocada pelo roubo do livro e resultou em diversas reações nos transeuntes e habitués locais, que narravam sobre o episódio e o fixavam o momento pelo clique fotográfico.

Como mais um ator emergente daquele cenário, há o lambe-lambe, Varceli Freitas, que incorporou a ressignificação daquele espaço e aderiu ao protesto proposto por Bier, como se este fosse de sua autoria. O motivo de sua adesão ao episódio, ou seja, se foi devido à lógica do comércio ou motivado pelo lucro a partir da produção de inúmeras fotografias que buscavam eternizar os acontecimentos, ou, ainda, se por uma atitude de adesão política, é o que menos interessa, pois o que ressalto aqui são as reações, as adesões e as narrativas diversas que emergiram deste protesto, que comunicou tensões pré-existentes fermentadas naquela Feira do Livro, transformando os espaços e os atores sociais, os quais passaram a ocupar papéis distintos depois do evento "o roubo do livro".

Para George Simmel, "a sociabilidade é o jogo no qual se 'faz de conta' que são todos iguais e, ao mesmo tempo, se faz de conta que cada um é reverenciado em particular; e 'fazer de conta' não é mentira mais do que o jogo ou a arte são mentiras devido ao seu desvio de realidade" (apud MORAES FILHO, 1983, p. 173). O contexto urbano, portanto, é um cenário privilegiado para evidenciarmos o jogo dessas formas de sociabilidade, no qual se expressam diferenciados estilos de vida.

O microevento do roubo do livro é, por fim, uma performance entre tantas ligada às experiências cotidianas distintas que propiciam processos de interações e sociações na Rua da Praia, ou ainda, em qualquer rua da cidade que conforme paisagens díspares.

\section{Referências}

ECKERT, Cornelia, ROCHA, Ana Luiza Carvalho da. O tempo e a cidade. Porto Alegre: Editora UFRGS, 2005. 
ECKERT, Cornelia. "A cultura do medo e as tensões do viver a cidade: narrativa e trajetória de velhos moradores de Porto Alegre" In: MINAYO, Maria Cecilia de Souza e COIMBRA JR. Carlos E. A. (Org.). Antropologia, Saúde e Envelhecimento. Rio de Janeiro: Editora Fiocruz, 2002. p. 73 a 102.

FONSECA, Cláudia. "Antropologia, Educação e Cidadania". In: Revista do GEMPA - Grupo de Estudos em Educação, Metodologia de Pesquisa e Ação, $n^{\circ}$ 3, Porto Alegre, março de 1994. Texto consultado através do site: <http://www.smec.salvador.ba.gov.br/site/documentos/espacovirtual/espaco-escola/professor/artigos/antropologia....pdf $>$.

GRAVINA, Heloísa Corrêa. Ser da Praça: Performance- Etnografia na Praça da Alfândega. Porto Alegre: Dissertação defendida no Programa de Pós Graduação em Antropologia Social: UFRGS, 2006.

LANE, Jill. Reverend Billy: Preaching, protest and postindustrial flânerir.: TDR / The Drama Review, 1 March 2002.

LIMA, Roberto Kant de. "Administração de conflitos, espaço público e cidadania: uma perspectiva comparada”. In: Civitas - Revista de Ciências Sociais, Vol. 1, Número 2, 2001. Texto consultado através do site: $\langle$ http://revistaseletronicas.pucrs.br/ojs/index.php/civitas/article/view/73>.

MAFFESOLI, Michael. “O poder dos espaços de celebração”. In: Revista Tempo Brasileiro. Rio de Janeiro, número 116, 1994.

MATTA, Roberto da. A casa e a rua: espaço, cidadania, mulher e morte no Brasil. São Paulo, SP: Editora Brasiliense, 1985.

MORAES FILHO, E. (Org.). Simmel. São Paulo, Editora Ática, 1983.

PEIRANO, Mariza. “A análise antropológica de rituais”. In: Série Antropologia, n. 270. Brasília: Editora da UNB, 2000. p. 01-35.

PEIXOTO, Clarice Ehlers. Envelhecimento e Imagem. As fronteiras entre Paris e Rio de janeiro. São Paulo: Annablume, 2000.

TURNER, Victor. O Processo Ritual. Estrutura e Antiestrutura. Petrópolis: Vozes, 1974.

TURNER, Victor. "The Anthropology of performance". In: TURNER, Victor. The Anthropology of performance. New York: PAJ Publications, 1992.

\section{Fontes jornalísticas}

Autor desconhecido. “A decepção do artista”. Zero Hora, 18/10/2007, p. 49.

Autor desconhecido. "Memórias da cidade que não existe mais". Zero Hora, Segundo Caderno 18/10/2007, p. 07.

Autor desconhecido. "Um vândalo no meio do caminho". Zero Hora, 18/10/2007, p. 38. 
Autor desconhecido. "Vandalismo noturno". Zero Hora, 18/10/2007, p. 62.

Ludwing, Paulo. "Porta de prédio é levada da Rua da Praia". Zero Hora, 13/01/2009, p. 35.

Santana, Paulo. “O livro roubado". Zero Hora, 18/10/2007, p. 63.

Santos, Pedro Paulo José. "Vandalismo". Zero Hora, 18/10/2007, p. 62. 